\title{
Evaluation of physicochemical properties of curcumin nanoemulsion with food grade emulsifiers
}

\author{
Eun Ji Kim, Gye Hwa Shin* \\ Department of Food and Nutrition, Kunsan National University, Gunsan 54150, Korea
}

\section{식품용 유화제에 따른 커큐민 나노에멀젼의 이화학적 특성 평가}

\author{
김은지 · 신계화* \\ 군산대학교 식품영양학과
}

\begin{abstract}
Curcumin-loaded nanoemulsions (Cur-NEs) were prepared with medium chain tryglyceride (MCT) oil, soybean lecithin and various biopolymers such as glucidex, whey protein isolate (WPI), and hydroxypropyl methylcellulose (HPMC) as co-surfactants or stabilizers by ultrasonic homogenization. The Cur-NEs were characterized by measuring the mean particle size, polydispersity index (PDI) and zeta potential at various ratios of lecithin and biopolymer concentrations. The type of biopolymer also affected the particle formation and mean particle size of the Cur-NEs. The mean particle sizes of the Cur-NEs increased significantly from $204.7 \pm 0.7 \mathrm{~nm}$ for Cur-NEs with only lecithin to $265.8 \pm 2.58 \mathrm{~nm}$ for Cur-NEs with HPMC. The storage stability of the Cur-NEs was investigated by comparing their particle size and viscosity before and after storage at $4^{\circ} \mathrm{C}$ and $25^{\circ} \mathrm{C}$ for 2 months. Phase separation was observed for the Cur-NEs with WPI after storage at $25^{\circ} \mathrm{C}$ for 2 months, while the particle size of the Cur-NEs increased significantly by $5.8-11.6 \%$ after storage at $4^{\circ} \mathrm{C}$ for 2 months. The mophology of the Cur-NEs observed by transmission electron microscopy (TEM). The TEM results indicated that stable Cur-NEs can be prepared by using lecithin, glucidex, and HPMC as a stabilizer.
\end{abstract}

Key words : curcumin, nanoemulsion, glucidex, whey protein isolate, hydroxypropyl methylcellulose

서 론

강황(Curcuma longa L.)의 뿌리 부분에서 추출되는 커큐 민(curcumin)은 자연적인 폴리페놀계 소수성 화합물로 양 념 및 식품 첨가물로 많이 사용하고 있는 노란색 향신료로 알려져 있다(Kaur와 Das, 2011). 최근 커큐민의 생물학적 기능에 대한 광범위한 연구에 따르면 커큐민은 항산화, 항염증, 항암 및 항바이러스 작용 등의 다양한 기능을 뛰어 나다고 알려지면서 인간 건강을 향상시키기 위한 의약품 및 식이 보조제의 성분으로 사용되어 왔다(Kuo 등, 1996;
Lantz 등, 2005; Kunnumakkar 등, 2008; Kaur와 Das, 2011). 커큐민은 인체에 많은 유익한 효과를 보이는 것으로 밝혀지고 있음에도 불구하고 수용액에는 잘 녹지 않는 난용성 물질로 알려져 있다(Xiao 등, 2013). 특히 식품 및 의약품 제형에 함유된 생리 활성 성분으로써 커큐민의 적용은 위장관에서의 낮은 용해도 및 현저하게 낮은 생체 이용률로 혈장 및 조직에서 흡수가 저하되고, 빠르게 배설 로 이어진다고 알려져 있다(Xiao 등, 2013; Salehi 등, 2019). 커큐민은 $\mathrm{pH}$ 가 알칼리인 경유, 빛에 노출되었을 때, 또는 높은 온도와 위장 효소에 노출되었을 때에 흡수가 급격히

\footnotetext{
*Corresponding author. E-mail : winnie19@kunsan.ac.kr, Phone : +82-63-469-4634, Fax : +82-63-469-2085

Received 30 September 2019; Revised 29 October 2019; Accepted 29 October 2019.

Copyright (c) The Korean Society of Food Preservation.

This is an Open Access article distributed under the terms of the Creative Commons Attribution Non-Commercial License (http://creativecommons.org/licenses/by-nc/4.0) which permits unrestricted non-commercial use, distribution, and reproduction in any medium, provided the original work is properly cited.
} 
저하되며(Salehi 등, 2019), 산성 $\mathrm{pH}$ 에서는 다른 조건에 비하여 안정하지만 식품첨가물과 의약품으로 사용하기에 는 매우 제한적이다. 이러한 단점을 극복하기 위하여, 커큐 민을 캡슐화함으로써 가공 및 저장 환경에서의 물리적, 화학적 안정성을 증가시킬 수 있다. 최근에는 커큐민을 나노화하는 연구들이 활발하게 진행되고 있으며, 그 중에 서도 지질 전달체를 이용한 나노 에멀젼 기술이 많이 이용 되고 있다(Cho 등, 2014; $\mathrm{Ma}$ 등, 2017). 이러한 나노에멀젼 기술은 생리활성이 높은 기능성 물질들의 현저히 낮은 용해도를 증가시킬 수 있는 것으로 보고되고 있어(Cho 등, 2014), 액상식품으로의 적용을 용이하게 할 수 있을 것으로 판단된다.

나노에멀젼 제형은 포집된 지용성 물질들을 외부 환경 으로부터 보호하여 안정한 상태로 체내의 흡수를 증가 시킬 수 있으며(Jo 등, 2016), 일반적으로 $500 \mathrm{~nm}$ 보다 작은 평균 입자의 크기로 이루어지며, 입자 크기가 작기 때문에 마이크로에멀젼보다 상대적으로 광학적 투명도가 높고, 안정성이 매우 우수하다고 보고되고 있다(Katouli 등, 2018). 나노에멀젼은 소화 시 체내 흡수율이 증가되는 장 점이 있어, 이를 이용한 식품, 음료 및 제약 산업에 다양한 응용이 이루어지고 있다(Katouli 등, 2018).

현재까지 나노에멀젼 기술을 식품에 적용하기 위하여, 인체에 유해한 화학적 유화제를 식품용 유화제로 대체하 고자 하는 연구들이 꾸준히 진행되어 왔다. 에멀젼 제조 시 다양하게 이용되고 있는 바이오폴리머들은 유화제와 유사한 특성을 지니고 있으며, 인체에 무해하며, 계면활성 제의 대체성분으로 에멀젼의 안정성을 높이는데 주로 사 용될 수 있다고 보고되었다(Jo 등, 2016). 단백질계 바이오 폴리머들은 양친매성의 특징을 가지며, 오일상과 수상의 경제면에 잘 흡수되어, 표면장력을 낮추어 줌으로써, 그들 의 안정성 및 기능성을 유지하여, 유화제로써의 역할을 잘 수행할 수 있는 것으로 알려져 있다. 반면, 탄수화물계 바이오폴리머들은 연속상에서 점도를 증가시켜 주어 에 멀젼의 안정성 증대에 크게 기여하는 유화제로 사용될 수 있다고 보고되었다(Silva 등, 2015).

일반적으로 나노에멀젼을 제조하는 방법으로는 저에너 지(low-energy) 에멀젼화 방법과 고에너지(high-energy) 에 멀젼화 방법으로 크게 분류할 수 있다(Wlstra, 1993). 유화 제의 계면화학적 성질을 기반으로 형성되는 저에너지 방 법으로는 자발적(spontaneous) 에멀젼화(Shafiq 등, 2007), 자기결합(self-assembly) 에멀젼화(Pons 등, 2003), 상전이 온도 유화법(phase inversion temperature method) 등이 있으 며(Izquierdo 등, 2004), 이러한 방법들은 낮은 에너지 공급 조건에서 나노에멀젼 형성이 가능하지만 평형상태에 도 달하는 조건이 까다롭고, 대량의 나노에멀젼 형성의 쉽지 않은 것으로 보고되어 있다(Forgiarini 등, 2001). 반면, 큰
파쇄 에너지를 필요로 하는 고에너지 에멀젼화 방법은 초음파균질기(ultrasonic homogenization)(Jafari 등, 2006) 또는 초고압균질기(high pressure homogenization)(Tan과 Nakajima, 2005) 등과 같은 큰 유화장치를 이용하여 나노에 멀젼을 제조한다고 보고된다. 초음파 균질기를 이용한 에 멀젼화 방식은 유화제의 존재하에 초음파에너지를 가할 때 생성되는 내파 진공 거품으로 인해 용매 주위에 큰 충격파가 발생되고, 높은 속도의 추진력으로 인해 나노에 멀젼이 만들어지게 된다(Maa와 Hsu, 1999).

본 연구에서는 나노에멀젼 제조 시 식품에 적용이 가능 한 유화제로서, lecithin, glucidex, hydroxypropyl methylcellulose(HPMC), 및 whey protein isolate(WPI)을 선정하여 초음파 균질 처리를 통한 나노에멀젼을 제조하였다. 각각 유화제에 따른 나노에멀젼의 물리적 변화와 $\mathrm{pH}$ 및 저장 기간에 따른 안정성 변화를 관찰하였고, transmission electronic microscopy(TEM)에 의해 입자의 형태를 비교 관찰하였다.

\section{재료 및 방법}

\section{실험재료}

본 연구에서 사용한 커큐민은 Acros Organics (Morris, $\mathrm{NJ}, \mathrm{USA}$ )에서 구입했다. 비이온성 계면활성제로 사용되 는 대두 lecithin은 Junsei Chemical(Tokyo, Japan)에서 구입 하였다. Whey protein isolate(WPI)는 Sungpoong(Anseoung, Korea)에서, hydroxypropyl methylcellulose(HPMC)는 Lotte Fine Chemical(Incheon, Korea), glucidex는 Samyang Corp.(Seongnam, Korea)에서 제공 받았다. Medium chain triglyceride(MCT)는 Now Foods(Bloomingdale, IL, USA)에 서 구입하였다.

\section{나노에멀젼의 제조}

커큐민을 함유한 수중유적형(oil in water, $\mathrm{O} / \mathrm{W}$ ) 나노에 멀젼은 초음파 균질처리기(VCX 750 apparatus, Sonics \& Materials, Newtown, CT, USA)를 이용하여 최대 $750 \mathrm{~W}$ 파워로 10 분 동안 처리를 통해 제조하였으며, 바이오폴리 머 유화제의 종류별로 각각 제조하였다. 나노에멀젼은 $\mathrm{MCT}$ 오일을 분산상으로 하여 $0.5 \%(\mathrm{w} / \mathrm{w})$ 커큐민을 첨가하 여 제조하였으며, 연속상으로는 lecithin을 증류수에 충분 히 용해시키고, 각각의 바이오폴리머들을 $1 \%(\mathrm{w} / \mathrm{v})$ 로 용해 시켜 제조하였다. 분산상인 $\mathrm{MCT}$ 오일은 $80^{\circ} \mathrm{C}$ 에서 한 시간 동안 교반 후 커큐민을 넣어 2 시간 동안 분산시켜 주었으 며, 연속상에는 $1 \%(\mathrm{w} / \mathrm{v})$ 에 해당하는 HPMC, WPI, glucidex 를 각각 레시틴을 녹인 증류수에 용해시켰다. 각각 준비한 연속상과 분산상을 혼합하고, 고속균질기(high speed homogenizer, ultra-turrax T18, Hucom System Co., Ltd., 
Seoul, Korea)를 이용하여, $12,000 \mathrm{rpm}$ 속도로 10 분간 교반 하여 마이크로에멀젼을 제조하였다. 이후 초음파 균질기 를 이용하여 15 분간 처리하여 나노에멀젼을 제조하였다.

\section{입자크기 및 입자분포도 측정}

커큐민 나노에멀젼의 평균 입자크기, polydispersity index(PDI) 및 제타전위는 dynamic light scattering 원리를 이용하여 Zetasizer Nano-ZS90(Malvern Instruments, Worcestershire, UK)를 이용하여 분석하였다. 나노에멀젼 $2 \mathrm{~mL}$ 를 취하여 3회 반복 측정하여 평균값으로 나타내었다.

\section{저장기간에 따른 물리적 안정성 평가}

제조한 나노에멀젼은 $4^{\circ} \mathrm{C}$ 에서 2 개월 동안 보관 후 입자 의 안정성 평가를 위하여 입자의 크기와 PDI값의 변화를 관찰하였다. 또한, 2 개월 동안 $4^{\circ} \mathrm{C}$ 와 $25^{\circ} \mathrm{C}$ 에서 나노에멀젼 을 저장한 후 외관의 변화를 관찰하였다.

\section{Transmission electron microscopy(TEM) 분} 석을 이용한 입자 형태의 관찰

나노에멀젼 입자의 형태적 특성은 TEM 장비를 이용하 여 관찰하였다. 나노에멀젼 샘플 용액 한 방울을 탄소 피복 그리드 상에 침착시키고 1 분 동안 유지시켰다. 과량의 용 액을 여과지로 제거하였다. $2 \%(\mathrm{w} / \mathrm{w})$ 인산 텅스텐산 용액 한 방울을 적용하여 약 1 분 동안 샘플을 염색하였다. TEM 이미지를 얻기 위하여 모든 샘플을 실온에서 12 시간 이상 건조시킨 후 관찰하였다.

\section{$\mathrm{pH}$ 의 영향}

$\mathrm{pH}$ 에 대한 입자 안정성을 평가하기 위하여 potassium hydrogen phthalate와 $\mathrm{HCl}$ 을 이용한 완충용액 $\left(\mathrm{pH} 4,25^{\circ} \mathrm{C}\right)$ 와 $\mathrm{Borax}$ 와 $\mathrm{NaOH}$ 를 이용한 완충용액 $\left(\mathrm{pH} 10,25^{\circ} \mathrm{C}\right)$ 을 제조 하여 사용하였다. 제조된 나노에멀젼과 $\mathrm{pH}$ 완충용액을
혼합하여 나노에멀젼 입자의 크기와 PDI 변화를 $25^{\circ} \mathrm{C}$ 에서 관찰하였다.

\section{커큐민 나노에멀젼의 점도 측정}

커큐민 함유 나노에멀젼의 점도는 $250 \mathrm{~mL}$ 에 담아 실온 $\left(25 \pm 1^{\circ} \mathrm{C}\right)$ 에서 점도계(DV3T, AMETEK Brookfield, Middleboro, MA, USA)를 이용하여 나노에멀젼의 점도를 측정하 였다. $4^{\circ} \mathrm{C}$ 에서 2 개월 동안 저장 후 나노에멀젼의 점도 변화 도 관찰하였다.

\section{통계처리}

모든 분석 결과는 3 반복으로 실험한 평균값이며, 각 분 석결과에 대한 통계분석은 SPSS 통계프로그램(Statistics Ver. 24.0 IBM, Chicago, IL, USA)을 이용하였고, Duncan's multiple range test를 이용하여 평균치 간의 유의성을 $\mathrm{p}<0.05$ 수준에서 실시하여 각 시료간의 유의적인 차이를 검증하였다.

\section{결과 및 고찰}

\section{바이오폴리머 종류에 따른 나노에멀젼 입자의 특성}

Fig. 1(A)는 커큐민 나노에멀젼 제조를 위한 ternary phase diagram으로 오일상, 수상 및 유화제 함량비율에 따 른 최적 조건을 찾기 위한 것이다. 나노에멀젼을 제조하였 을 때 상분리가 일어나지 않고, 커큐민이 침전되지 않은 균일한 상태의 에멀젼의 비율 조건을 $\bigcirc$ 로 표시하였으며, 상분리가 관찰되는 조건은 $\times$ 로 표시하였다. Fig. 1(B)와 Fig. 1(C)는 각각 다른 바이오폴리머를 이용하여 제조한 나노에멀젼의 입자의 크기와 PDI 및 제타전위를 나타낸 것이다. 커큐민 나노에멀젼은 일차적으로 고속 균질기를 이용하여 마이크로에멀젼을 형성하였고, 이차적으로 초 음파 균질 처리를 함으로써 나노에멀젼을 제조할 수 있었
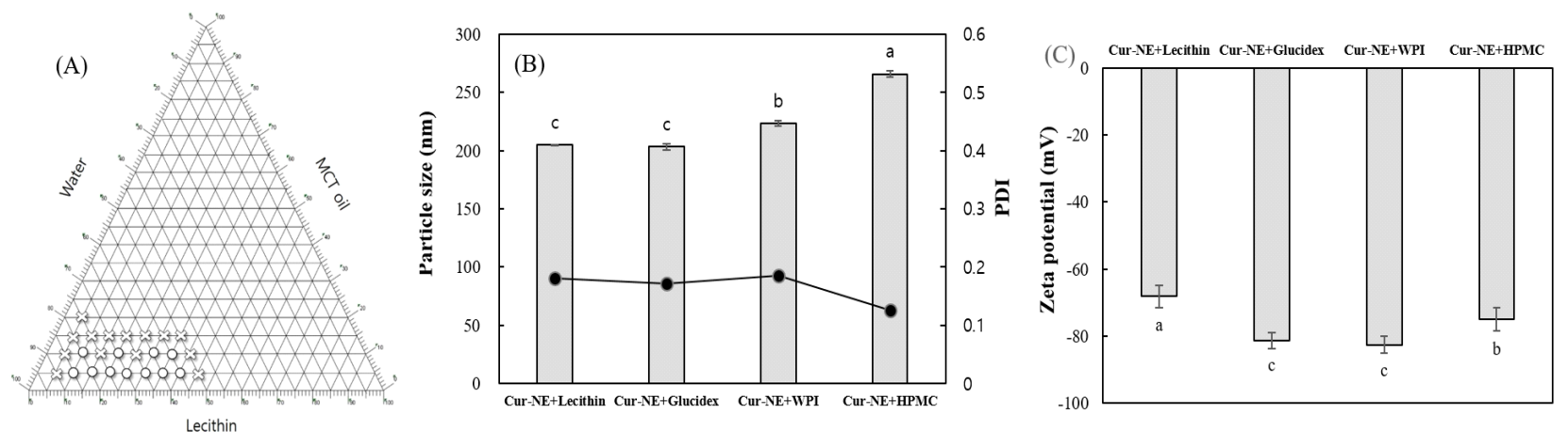

Fig. 1. (A) Ternary phase diagram, (B) particle size and PDI, and (C) zeta potential of curcumin-loaded nanoemulsions (Cur-NEs) containing lecithin, glucidex, whey protein isolate (WPI) and hydroxypropyl methylcellulose (HPMC). 
다. 바이오폴리머를 함유하지 않고, 레시틴만으로 제조한 커큐민 나노에멀젼은 평균 $204.7 \pm 0.7 \mathrm{~nm}$ 의 입자크기를 나타 내었으며, PDI 값은 $0.181 \pm 0.018$, 제타전위는 $-68.11 \pm 3.30$ $\mathrm{mV}$ 로 매우 안정한 나노에멀젼이 제조되었음을 확인하였 다. 한편, glucidex를 유화제로 첨가한 경우, 입자의 크기는 가장 작게 측정이 되었으나, lecithin만을 유화제로 사용한 경우와 비교하였을 때 유의적인( $p>0.05)$ 차이는 없는 것으 로 나타났다. WPI의 경우, 입자의 크기는 평균 $223.5 \pm 2.21$ $\mathrm{nm}$ 이고, $\mathrm{PDI}$ 는 $0.186 \pm 0.01$ 로 lecithin으로만 제조한 나노에 멀젼과 glucidex를 첨가한 나노에멀젼과 비교하였을 때 입자의 크기가 증가하였으며, 유의적 $(\mathrm{p}<0.05)$ 으로 차이가 있음을 관찰하였다. $\mathrm{HPMC}$ 를 유화제로 첨가한 나노에멀 젼의 경우가 가장 입자가 크게 관찰되었다. 제타전위 값은 lecithin으로 제조한 나노에멀젼보다, 바이오폴리머들을 유화제로 첨가한 경우 유의적 $(\mathrm{p}<0.05)$ 으로 증가하는 것으 로 관찰되었다(Fig. 1C).

일반적으로 입자의 분산지수를 나타내는 PDI 값은 입자 의 분산정도를 나타내는 지표로써 범위는 0 에서 1 사이의 값으로 표시된다. 입자의 분산지수가 0.3 이하인 경우는 단분산상 형태이며, 그 이상의 값을 나타낼 경우, 중분산상 이나 다분산상 형태의 에멀젼 입자가 분포되어 있음을 알 수 있다(Jo 등, 2016). 또한, 제타전위 값이 $+30 \mathrm{mV}$
이상이거나 $-30 \mathrm{mV}$ 이하인 경우, 즉 제타전위의 절대값 이 증가하는 경우 입자의 안정성은 증대되는 반면, 제타전 위의 절대치가 0 에 가까워지면 입자는 응집하기 쉬워진다 고 보고되어 있다(Lim 등, 2010). 본 실험에서 glucidex, $\mathrm{WPI}, \mathrm{HPMC}$ 를 유화제로 첨가한 모든 샘플에서 제타전위 의 절대값이 $81.25 \pm 2.43 \mathrm{mV}, 82.53 \pm 2.49 \mathrm{mV}, 74.96 \pm 3.41$ $\mathrm{mV}$ 로 각각 나타나 입자의 안정성이 높은 것을 관찰할 수 있었다.

\section{저장 중 물리적 안정성 평가}

입자의 크기와 PDI 값을 기초로 하여 커큐민 나노에멀 젼의 물리적 안정성을 평가하였다. Fig. 2(A)에서 보는 것 과 같이 2개월 동안 저장 후 입자의 크기는 레시틴 첨가한 시료의 경우 약 $11.68 \%$ 증가하였고, 바이오폴리머를 유화 제로 첨가한 시료들의 경우 $5.86 \%$ 에서 $8.21 \%$ 가 증가하여 레시틴만을 유화제로 사용한 경우와 비교하여 입자 크기 의 변화가 적은 것을 관찰할 수 있었다. 또한, 입자의 분산 도를 나타내 주는 PDI 값이 전반적으로 0.19 에서 0.20 사이 로 나타나 2개월 후에도 입자들은 매우 고르게 분산되어 있음을 관찰할 수 있었다. 2 개월 저장 후 입자 크기의 변화 는 다른 바이오폴리머를 섞지 않은 lecithin의 경우가 $11.6 \%$ 증가로 가장 크게 변화하였으며, WPI, HPMC를 유

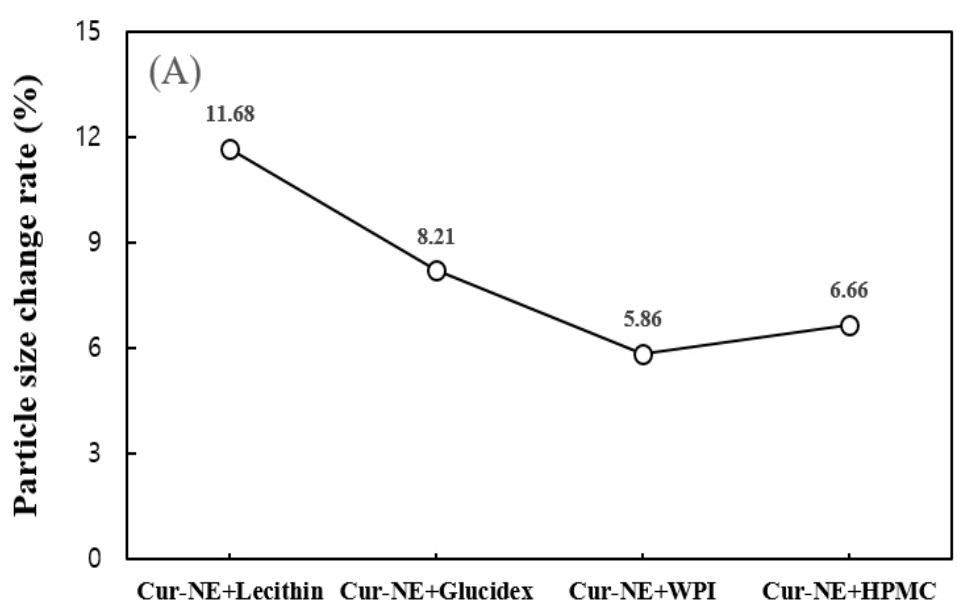

(B)

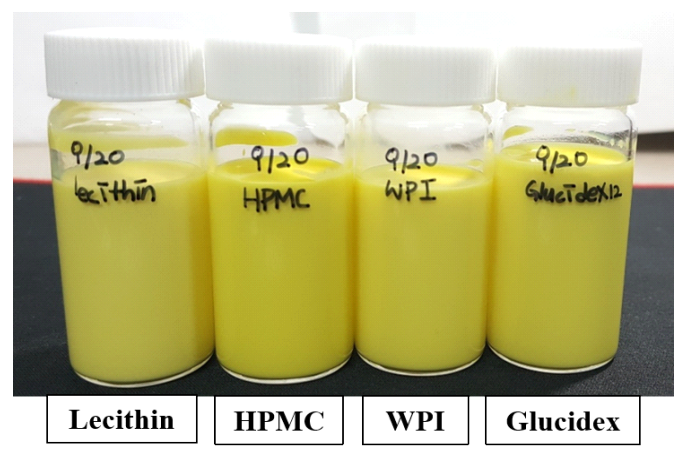

(C)

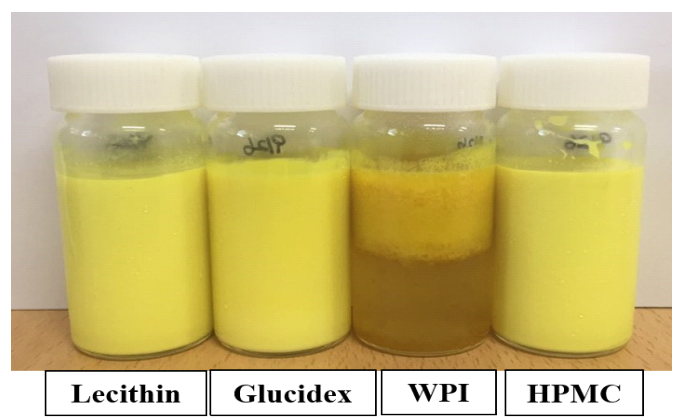

Fig. 2. (A) Particle size change rate and photographs of Cur-NEs+lecithin, Cur-NEs+glucidex, Cur-NEs+WPI, Cur-NEs+HPMC after storage at (B) $4^{\circ} \mathrm{C}$ and (C) $25^{\circ} \mathrm{C}$ for 2 months. 
화제로 이용한 나노에멀젼이 각각 $5.8 \%, 6.7 \%$ 로 상대적으 로 낮은 입자 크기의 변화를 관찰하였다. 기존의 연구된 논문들에 따르면, WPI와 같은 단백질계 유화제를 나노에 멀젼 제조에 이용한 경우, 입자의 안정성을 도모할 수 있는 것으로 보고되어 있다(Jo 등, 2016).

한편, Fig. 2(B)에서 보는 것과 같이 2 개월 동안 $4^{\circ} \mathrm{C}$ 와 $25^{\circ} \mathrm{C}$ 에서 저장 후 입자의 변화를 육안으로 관찰하여 보았 는데, $4^{\circ} \mathrm{C}$ 에서 저장한 경우는 외관상으로 전체 샘플에서 층분리 현상을 관찰할 수 없었으나, $25^{\circ} \mathrm{C}$ 에서 저장한 경우 WPI 샘플에서만 층분리가 일어나는 현상을 관찰할 수 있 었다(Fig. 2C).

\section{저장 중 점도의 변화}

Fig. 3에서 보는 것과 같이 초기 점도 변화는 lecithin 첨가한 샘플이 $2.77 \pm 0.05 \mathrm{cp}$ 로 점도가 가장 낮았고, glucidex와 WPI를 첨가한 샘플들은 각각 $3.17 \pm 0.1 \mathrm{cp}$ 와 $3.77 \pm 0.05 \mathrm{cp}$ 를 나타내었으며, $\mathrm{HPMC}$ 첨가한 샘플은 $33.43 \pm 0.05 \mathrm{cp}$ 로 가장 점도가 높은 것으로 확인되었다. 2 개 월 동안 $4^{\circ} \mathrm{C}$ 에서 저장 후 입자의 점도를 측정해본 결과, lecithin과 glucidex 첨가 샘플들은 점도 변화가 크지 않았으 나. WPI 첨가 샘플의 점도는 $3.77 \pm 0.05 \mathrm{cp}$ 에서 $12.1 \pm 0.23$ $\mathrm{cp}$ 로 약 3.2배가 증가하였으며, HPMC 첨가 샘플의 점도는 $33.43 \pm 0.05 \mathrm{cp}$ 에서 $94.75 \pm 1.11 \mathrm{cp}$ 로 약 2.83 배가 증가하는 것을 알 수 있었다. 다른 문헌에서는 입자의 크기가 상대적 으로 작은 나노에멀젼의 경우, 점도가 매우 낮게 측정된다 는 연구 결과들이 보고되었다(Lee와 Yoo, 2014).

\section{$\mathrm{pH}$ 의 영향}

Fig. 4는 pH 변화에 따른 커큐민 나노에멀젼의 입자크기 와 PDI 변화를 나타낸 것이고, Fig. 5는 $\mathrm{pH}$ 변화에 따른 커큐민 나노에멀젼의 상태를 나타내 주는 사진이다. $\mathrm{pH}$ 1 의 강산 조건에서는 커큐민 나노에멀젼은 불안정하고,

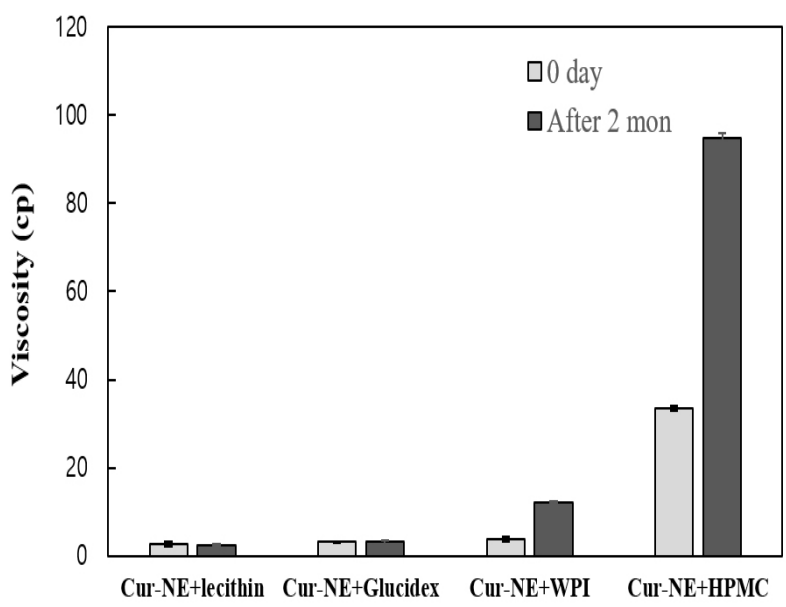

Fig. 3. Viscosity of Cur-NEs+lecithin, Cur-NEs+glucidex, CurNEs+WPI, and Cur-NEs+HPMC before and after storage at $4^{\circ} \mathrm{C}$ for 2 months.

응집과 에멀젼이 상분리되는 현상으로 입자크기를 측정 할 수 없었다. 특히 lecithin과 HPMC 첨가 샘플의 경우는 aggregation이 일어나는 것을 관찰할 수 있었고, glucidex와 WPI 첨가 샘플의 경우는 층분리가 일어났다. 한편, $\mathrm{pH}$ 4 에서는 모든 나노에멀젼의 입자의 크기가 증가하는 것을 관찰하였고, WPI를 유화제로 첨가한 경우, 나노에멀젼의 층 분리가 일어나 입자 크기 측정이 불가능하였다. PDI 값도 $\mathrm{pH}$ 4의 경우 모든 샘플들에서 증가하는 것을 볼 수 있었는데, 특히 $\mathrm{HPMC}$ 를 첨가한 나노에멀젼의 경우가 입 자의 크기와 PDI 모두 큰 증가폭을 보여주었다. $\mathrm{pH} 10$ 인 조건에서는 lecithin과 glucidex를 이용한 나노에멀젼의 입 자크기는 감소하는 반면, WPI와 $\mathrm{HPMC}$ 의 경우는 입자크 기가 증가하는 것을 관찰하였다. PDI 값은 모든 샘플에서 증가하였으며, 특히 WPI와 $\mathrm{HPMC}$ 를 첨가한 나노에멀젼 의 경우가 큰 증가폭을 보여주었다.
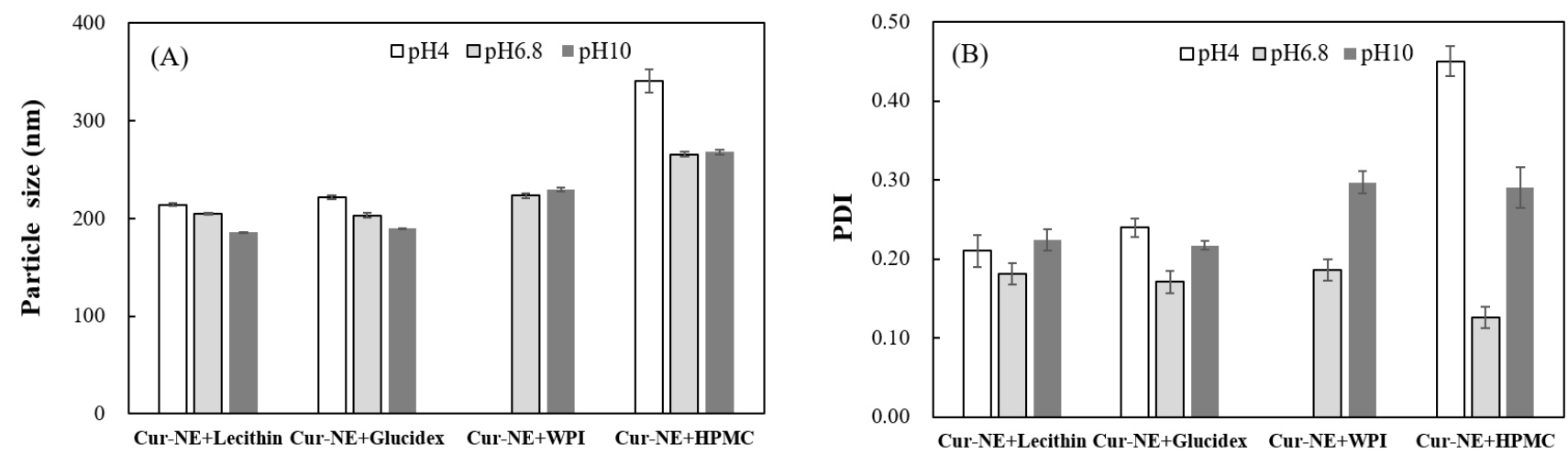

Fig. 4. Changes in (A) particle size and (B) PDI of Cur-NEs+lecithin, Cur-NEs+glucidex, Cur-NEs+WPI, and Cur-NEs+HPMC at different pHs. 

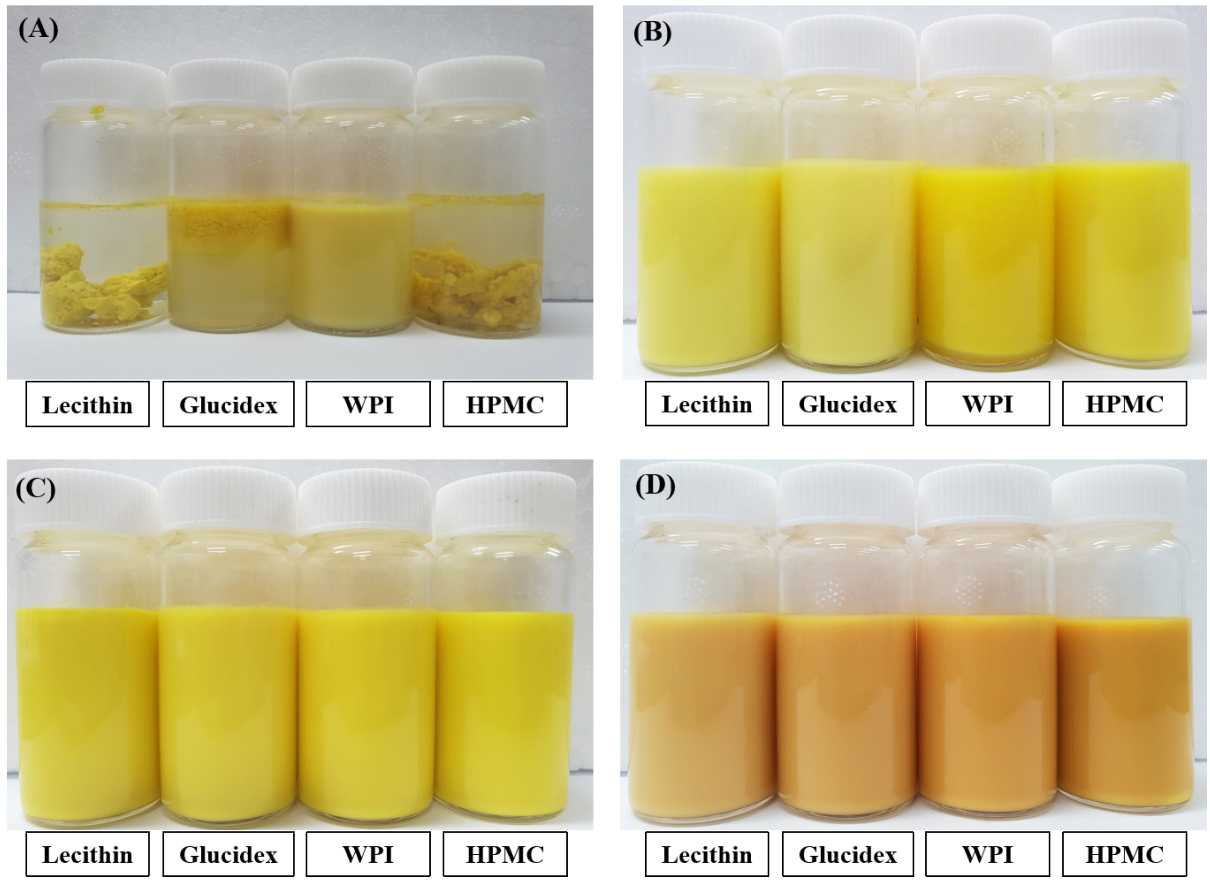

Fig. 5. Photographs of Cur-NEs+lecithin, Cur-NEs+glucidex, Cur-NEs+WPI, and Cur-NEs+HPMC at (A) pH 1, (B) pH 4, (C) pH 6.8, and (D) $\mathrm{pH} 10$.

일반적으로 커큐민은 중성이나 산성과 같은 낮은 $\mathrm{pH}$ 의 수용액에서는 용해되기 어려우며, 아세톤이나, 메탄올, 에 탄올, 알칼리 등과 같은 조건에서 조금 용해되는 난용성 성질을 가지고 있다고 알려져 있다(Cho 등, 2014). 특히 커큐민의 구조는 수용액이나 용매 내에서 enol형과 keto형 의 두 가지 이성체로 존재하며, 용매의 조건에 따라 가역적 으로 변형이 쉬운 물질로써, keto-enol tautomerism 현상을 관찰할 수 있다(Cavaleri와 Jia, 2017).

커큐민의 구조는 중성이나 산성 $\mathrm{pH}$ 조건이나 수용액 상태에서는 keto형으로 존재하며, 알칼리 조건에서는 enol 형으로 존재한다고 보고되어 있으며, keto형일 경우 커큐 민의 색깔이 노란색에 가깝고, enol형으로 존재할 경우 진한 주황색에서 붉은 갈색에 가까운 색으로 변화한다고 보고되어 있다(Jankun 등, 2016). 실제로 커큐민 나노에멀젼 샘플이 $\mathrm{pH} 7$ 이하의 샘플인 경우는 노란색을 강하게 띄는 반면, 알칼리 조건인 $\mathrm{pH} 10$ 에서는 커큐민 나노에멀젼의 색깔이 주황색으로 변화하는 것을 관찰할 수 있었다. 한편, 나노에멀젼의 $\mathrm{pH}$ 를 산성 조건이나 알칼리 조건으로 변화시 키고 단시간 내에 관찰하고 사진을 찍은 것으로 degradation products는 생성되지 않았을 것으로 판단이 된다.

\section{나노에멀젼 입자의 형태 관찰}

각각의 나노에멀젼 입자 형태는 투과전자현미경(TEM) 을 이용하여 입자의 형태와 분포 정도를 관찰하였다. 그
결과, 나노에멀젼의 입자 형태는 대부분의 샘플에서 둥근 형태로 관찰되었으며, 나노에멀젼 중에서도 $\mathrm{HPMC}$ 를 유 화제로 사용한 입자가 가장 동그란 입자의 형태를 가진 것을 볼 수 있었다(Fig. 6). 실제 입도분석을 통한 나노에멀 젼의 크기보다 TEM 사진상에서는 작게 나타는 것을 관찰 하였는데, 이것은 샘플 건조 과정에서 입자 내의 수분이 증발되면서 입자의 크기가 축소되는 것으로 생각되었다. 또한, $\mathrm{HPMC}$ 를 유화제로 첨가한 나노에멀젼의 경우 입자 의 밀도가 매우 높게 형성되는 것을 관찰되었으며, 이것은 $\mathrm{HPMC}$ 가 에멀젼 형성에 적합한 유화제로써의 역할을 한 다고 판단이 된다.

\section{요 약}

본 연구에서는 난용성 천연생리활성 물질인 커큐민의 용해성을 높이고, 실제 식품에 적용을 고려하여, 식품용 유화제만을 사용하여 초음파 균질처리를 통해 나노에멀 젼을 제조하였다. 제조된 나노에멀젼의 다양한 물질적 특 성은 유화제로 쓰인 바이오폴리머의 종류에 따라 다르게 나타났으며, 나노에멀젼 입자의 크기는 glucidex를 유화제 로 사용한 경우가 가장 작게 나타났고, $\mathrm{HPMC}$ 의 경우가 가장 크게 나타났다. 시간의 경과에 따른 나노에멀젼 입자 의 크기가 서로 다른 유화제별로 5.8-11.6\% 정도의 증가 폭을 관찰할 수 있었다. $\mathrm{pH}$ 별로 입자의 크기 변화를 관찰하 

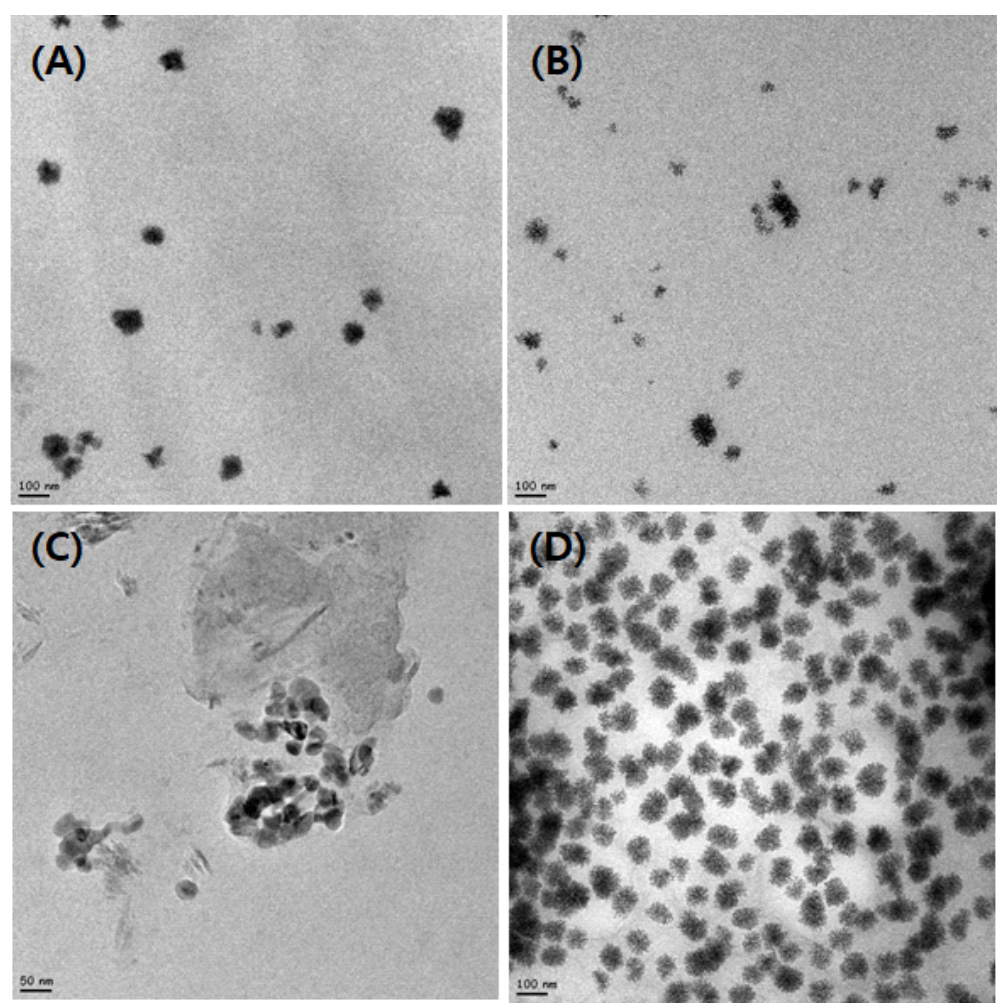

Fig. 6. Transmission electron microscope (TEM) images of (A) Cur-NEs+lecithin, (B) Cur-NEs+glucidex, (C) Cur-NEs+WPI, and (D) Cur-NEs+HPMC.

였을 때, 강산 조건인 $\mathrm{pH} 1$ 에서는 입자의 응집과 층분리 되는 현상을 관찰하였고, $\mathrm{pH}$ 4에서는 전반적으로 입자의 크기와 PDI 값이 모두 증가하였으며, WPI는 층분리 현상이 일어났다. 알칼리 조건인 $\mathrm{pH} 10$ 에서는 lecithin과 glucidex 를 첨가한 나노에멀젼은 입자의 크기가 감소하는 반면, $\mathrm{WPI}$ 와 $\mathrm{HPMC}$ 를 첨가한 나노에멀젼의 입자는 증가하는 것을 관찰하였다. $\mathrm{pH} 10$ 조건에서 $\mathrm{PDI}$ 값은 모두 증가하는 경향을 볼 수 있었다.

\section{감사의 글}

이 논문은 2016학년도 군산대학교 신임교수 연구비 지 원에 의하여 연구되었음.

\section{Conflict of interests}

The authors declare no potential conflict of interest.

\section{ORCID}

Eun Ji Kim https://orcid.org/0000-0002-6217-3877

Gye Hwa Shin https://orcid.org/0000-0002-1891-9053

\section{Reference}

Cavaleri F, Jia W. The true nature of curcumin's polypharmacology. J Prev Med, 2, 1-11 (2017)

Cho YJ, Lee SB, Lee JK, Kwon YJ. Preparation of nanoemulsions containing curcumin by high pressure homogenization. Food Eng Prog. 18, 341-347 (2014)

Forgiarini A, Esquena J, Gonzalez C, Solans C. Formation of nano-emulsions by low-energy emulsification methods at constant temperature. Langmuir, 17, 2076-2083 (2001)

Izquierdo P, Esquena J, Tadros ThF, Dederen JC, Feng J, Garcia-Celma MJ, Azemar N, Solans C. Phase behavior and nano-emulsion formation by the phase inversion temperature method. Langmuir, 20, 6594-6598 (2004)

Jafari SM, He Y, Bhandari B. Nano-emulsion production by sonication and microfluidization-A comparison. Int $\mathrm{J}$ Food Prop, 9, 475-485 (2006)

Jankun J, Wyganowska-Swiatkowska M, Dettlaff K, Jelinska A, Surdacka A, Watrobska-Swietlikowska D, SkrzypczakJankun E. Determining whether curcumin degradation/ condensation is actually bioactivation (Review). Int $\mathrm{J}$ Mol Med, 37, 1151-1158 (2016) 
Jo YJ, Kim HY, Kwon YJ. Influence of biopolymer emulsifier on the characteristics of curcumin nanoemulsions. Food Eng Prog, 20, 321-327 (2016)

Katouli M, Polychminatou V, Tzia C. Optimization of water in olive oil nano-emulsions compositions with bioactive compounds by response surface methodology. LWT-Food Sci Technol, 89, 740-748 (2018)

Kaur S, Das M. Functional foods: An overview. Food Sci Biotechnol, 20, 861-875 (2011)

Kunnumakkara AB, Anand P, Aggarwal BB. Curcumin inhibits proliferation, invasion, angiogenesis and metastasis of different cancers through interaction with multiple cell signaling proteins. Cancer Lett, 269, 199-225 (2008)

Kuo ML, Huang TS, Lin JK. Curcumin, an antioxidant and anti-tumor promoter induces apoptosis in human leukemia cells. Biochim Biophys Acta, 1317, 95-100 (1996)

Lantz RC, Chen GJ, Solyom AM, Jolad SD, Timmermann BN. The effect of turmeric extracts on inflammatory mediator production. Phytomedicine, 12, 445-452 (2005)

Lee YE, Yoo IS. Effect of storage temperature on the dispersion stability of O/W nano-emulsion. Korean Soc Biotechnol Bioeng J, 29, 385-391 (2014)

Lim JS, Gang HJ, Yoon SW, Kim HM, Suk JW, Kim DU, Lim JK. Preparation and its stability of a coenzyme Q10 nanoemulsion by high pressure homogenization with different valve type conditions. Korean J Food Sci Technol, 42, 565-570 (2010)

Ma P, Zeng Q, Tai K, He X, Yao Y, Hong X, Yuan F. Preparation of curcumin-loaded emulsion using high pressure homogenization: Impact of oil phase and concen- tration on physicochemical stability. LWT-Food Sci Technol, 84, 34-46 (2017)

Maa YF, Hsu CC. Performance of sonication and microfluidization for liquid-liquid emulsification. Pharm Dev Technol, 4, 233-240 (1999)

Pons R, Carrera I, Caelles J, Rouch J, Panizza P. Formation and properties of miniemulsions formed by microemulsions dilution. Adv Colloid Interface Sci, 106, 129-146 (2003)

Salehi B, Stojanovic-Radic Z, Matejic J, Sharifi-Rad M, Anil Kumar NV, Martins N, Sharifi-Rad J. The therapeutic potential of curcumin: A review of clinical trials. Eur J Med Chem, 163, 527-545 (2019)

Shafiq-un-Nabi S, Shakell F, Talegaonkar S, Ali J, Baboota S, Ahuja A, Khar RK, Ali M. Formulation development and optimization using nanoemulsion technique: A technical note. AAPS Pharm Sci Tech, 8, 1-6 (2007)

Silva EK, Rosa MTM, Meireles MAA. Ultrasound-assisted formation of emulsions stabilized by biopolymers. Curr Opin Food Sci, 5, 50-59 (2015)

Tan CP, Nakajima M. $\beta$-Carotene nanodispersions: Preparation, characterization and stability evaluation. Food Chem, 92, 661-671 (2005)

Wlstra P. Principles of emulsion formation. Chem Eng Sci, 48, 333-349 (1993)

Xiao Y, Chen X, Yang L, Zhu X, Zou L, Meng F, Ping Q. Preparation and oral bioavailability study of curcuminoidloaded microemulsion. J Agric Food Chem, 61, 36543660 (2013) 